\title{
Preliminary Experiments on the Rearing of Sea-Fish Larvæ.
}

\author{
By
}

\author{
Walter Garstang.
}

THE present paper contains an account of experiments made at the Plymouth Laboratory in the summer of 1899 with the object of determining the conditions necessary for the artificial rearing of seafish larvæ through the critical stages of their development. As is well known, the majority of the attempts which have hitherto been made in this direction have proved abortive, and such success as has been obtained has been limited to the survival of a very small proportion of the original stock of fry. There was therefore ample scope for new work upon the subject, especially for experiments based on comparative methods which should aim more particularly to elucidate the habits of fish larvæ under clearly contrasted conditions. In this way only did it appear possible to make further progress in our knowledge of the physiological peculiarities of the delicate fry and of the conditions which are essential to their healthy development in confinement. The successful issue of the present experiments is entirely attributable, I think, to the fact that they were not undertaken until practically undivided attention could be given to them, which enabled me to watch long and closely the habits of individual larvæ under different conditions, and under the guidance of these observations to modify and perfect the simple apparatus employed until the mortality became reduced to reasonable proportions.

The only records of successful experiments in the rearing of sea-fish larvæ are those of Dr. H. A. Meyer in 1878 with the Baltic herring, of Captain Dannevig in 1886 with the cod in Norway, and of Mr. Harald Dannevig in 1896 with the plaice at Dunbar.

Dr. Meyer* reared a number of larvæ of the Baltic winter herring from eggs which had been artificially fertilised on the Schlei River. The larvæ were confined in a large tub containing water from the Bay

* Biologische Beobachtungen bei künstlicher Aufzucht des Herings der Westlichen Ostsee. Berlin, 1878. (Translated in Report U.S. Fish Commission for 1878, pp. 629-38.) 
of Kiel. Half the water was changed daily, and was filtered before its introduction into the tub in order to remove all but the most minute organisms from the water. A considerable mortality among the larvæ took place after the tenth day, apparently from an insufficient supply of food of the right kind; but the beneficial effects which followed the subsequent introduction of unfiltered water (containing a richer supply of larger organisms) were so conspicuous that a number of the larvæ completed their metamorphosis and were reared to a length of 72 millimetres (nearly 3 inches), their age at this length being about five months. Unfortunately neither the number nor perceritage of the survivors is mentioned.

Captain Dannevig's* experiment was carried out on a greater scale. He placed about 500,000 young fry of the cod, which had been artificially hatched, into a large basin of sea-water attached to the Flödevigen hatchery on the south coast of Norway. The capacity of the basin was about 2,500 cubic metres ( 88,000 cubic feet), the greatest dimensions being:--length, 43 metres; breadth, 20 metres; depth, 5 metres (i.e. about 140 by 66 by 16 feet). During the first month the larvæ refused artificial food, and no plankton (minute floating life) was provided for them except such as was already present in the seawater. They were observed to attack, kill, and eat each other in considerable numbers, but were still too small to attack the numerous crab larvæ which were also present in the water. From the second month onwards, however, they ate considerable quantities of finely-powdered mackerel, which was given them twice a day, and their rate of growth greatly increased. At the end of the fifth month they had attained an average length of $115 \mathrm{~mm}$. ( $4 \frac{1}{2}$ inches), the largest caught being $157 \mathrm{~mm}$. (6 inches) long. At the eighth month the number of survivors was estimated to amount to "several thousands." This famous and most important experiment served Captain Dannevig's purpose in demonstrating that fry artificially hatched have the power to live, grow, and develop when set more or less at liberty; but it is clear that, strictly speaking, the demonstration is limited to a small percentage $\dagger$ (not more than one or two per cent.) of the original stock of larvæ. By the following April, i.e. when about a year old, some of the survivors were about a foot in length.

* Report of the Codfish Hatchery at Flödevig, Norway, for 1886. (Translated in Bull. U.S. Fish Commission, VII., 1887, pp. 113-19.)

+ Mr. Harald Dannevig, in a reference to his father's experiments, states that " most of the young fishes survived the following winter" (Fifteenth Report Scottish Fishery Board, part iii. p. 176). Although I have not seen the original report, this would appear from the American translation to be a mistake.

$\ddagger$ Ewart, Fifth Report Scottish Fishery Board, pp. 235, 244; McIntosh, British Food Fishes, p. 244 ; Cunningham, British Marketable Fishes, p. 287. 
According to Professor Ewart, * Dannevig also set free a number of young herring in the same pond. Some completed their metamorphosis, but the greater number fell victims to the hungry cod.

Lastly, in 1896, Mr. Harald Dannevig, $\dagger$ at the Dunbar hatchery, succeeded in rearing a number of plaice through their complete metamorphosis, in a glass carboy holding ten gallons of sea-water. Twelve hundred larvæ were introduced, but the proportion of the survivors is not stated, except that the healthy larvæ, from which alone the survivors were derived, formed the minority from the beginning. The water was changed once or twice a day, and plankton from the harbour was added twice a day. The water in the carboy was subject to convection currents, caused by inequalities in the temperature of the water and that of the surrounding air. To the gentle movements of the water, due to this cause, Mr. Dannevig attaches much importance. The oldest stage described by Dannevig is that of an average specimen of the forty-fifth day, which had been on the bottom of the jar for several

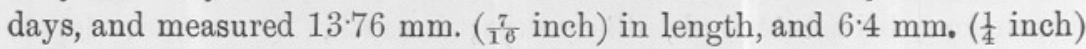
in breadth.

On the other hand, the difficulties of the problem are clearly brought out in the numerous unsuccessful experiments described by Cunningham, + and by MM. Fabre-Domergue and Biètrix, $\S$ as well as by the experiments known to have been made without result by other naturalists. Cunningham's experiments dealt chiefly with pelagic eggs; those of the French naturalists were based upon the demersal eggs of Cottus, but also included experiments with various kinds of pelagic eggs.

When the metamorphosis of a Teleostean larva has been accomplished, however, no further difficulty in rearing the young fish is experienced in most cases. This remark is particularly true of bottom fishes, such as flat fishes and gadoids, which have been repeatedly reared from the earliest adolescent stages even up to maturity, both in the Plymouth Laboratory and elsewhere; and it has been shown that the rate of growth is principally dependent upon the temperature and the food-supply to which the young fishes are subjected-conditions which can easily be controlled. There can, indeed, be no doubt that the possibilities of marine fish culture would be great and various, if we

* "On the Artificial Hatching and Rearing of Sea Fish." Fifth Report Scottish Fishery Board, 1886, p. 235.

† "On the Rearing of the Larval and Post-larval Stages of the Plaice and other Flat Fishes," loc. cit., pp. 175-192; also Sixteenth Report, pp. 223-4.

‡ "Experiments on the Rearing of Fish Larvæ in 1894," Journal of the Marine Biol.Assoc., iii., 1894, p. 206.

$\S$ "Recherches biologiques applicables à la Pisciculture Maritime." Ann. Sci. Nat. (viii.), t. 4, 1897, pp. 151-220. 
could bridge the gap in our knowledge as to the proper methods of treating the fry during the transformation from the larval to the adolescent stages. Promising as are the results of the experiments described above, it is clear that our knowledge of the conditions of larval life and development is quite inadequate so long as we can only ensure the survival of a minute percentage of the fry in our rearing experiments.

The species employed in my experiments was the "Butterfly Blenny" (Blennius ocellaris), which, at Plymouth, usually lays its eggs in the empty shells of whelks (Buccinum), in moderately deep water offshore (15 to 20 fathoms), whence relays of its eggs were easily obtainable with the dredge during the past summer (1899).

Although many offshore types of fish doubtless differ from it as to the special conditions requisite for their development, yet the observations made upon the development of this species cannot be without value in regard to the rearing of other offshore larvæ in captivity.

The eggs of the Butterfly Blenny have been described by Cunningham, * and the structure of the larva soon after hatching by Holt. $\dagger$ The larva at this stage is already well organised: the mouth is formed, the eyes pigmented, the yolk relatively small in quantity and moderately protuberant, and the pectoral fins well developed. On the other hand, the vertical fin membrane is still in the primitive undivided condition, the lower jaw is immovable, and the permanent skeleton has not yet made its appearance. The larva thus approximates in type to the early larva of Cottus and other demersal forms, and is more highly organised than the early larvæ derived from pelagic eggs such as those of flat fishes and gadoids, which indeed do not, strictly speaking, merit the term "larvæ," since they are merely embryos released from their shells, and incapable of capturing food for themselves. These so-called "pelagic larvæ" (which are not more peculiarly pelagic than the larvæ arising from demersal eggs) might well be distinguished from true larvæ, as "embryonic larvæ" or "embryo larvæ." The larva of the Butterfly Blenny, at the time of hatching, corresponds in its grade of organisation with a plaice larva five or six days old.

Holt assigns a length of $6.30 \mathrm{~mm}$. to the larva of the Butterfly Blenny when twelve to twenty-four hours old. This dimension considerably exceeds that of all the specimens which I have measured at a corresponding age, as will be seen from the following records of the size of four specimens, in millimetres :-

* Journ. M. B. A., i. 1891, p. 36, fig. 35.

† Ann. du Musée d'Hist. Nat. de Marseille, Zool., v., 1899, p. 45, pl. 6, fig. 63 ; Journ. M. B. A., v. p. 122. 


\begin{tabular}{|c|c|c|c|c|}
\hline & \multicolumn{3}{|c|}{3 to 4 hours old. } & 20 to 24 hours. \\
\hline Total length & $4 \cdot 6$ & $4 \cdot 5$ & $4 \cdot 6$ & ... $4 \cdot 6$ \\
\hline $\begin{array}{l}\text { Length from anterior extremity to } \\
\text { posterior surface of yolk }\end{array}$ & $1 \cdot 18$ & $1 \cdot 15$ & $1 \cdot 17$ & $1 \cdot 15$ \\
\hline Ditto to posterior surface of rectum. & $1 \cdot 62$ & 1.55 & 1.58 & $1 \cdot 60$ \\
\hline
\end{tabular}

These larvæ were hatched on August 4th from a batch of eggs dredged the same day. They were killed and preserved in weak formalin, and measured on August 5th. In view of the slight nature of the differences in my measurements of separate individuals, it is difficult to account for the discrepancy* between our observations, especially as I find the same length in early larvæ of another batch hatched on June 16th. The difference can scarcely be attributed to contraction of my specimens in formalin, since in the oldest of the above-mentioned larvæ the longest rays of the pectoral fin were seen to fall short of the anus by $0.15 \mathrm{~mm}$., whereas in Holt's specimen they extended $0.12 \mathrm{~mm}$. behind the anus. Moreover, in larvæ which had died a natural death and become opaque, the pectoral fin-rays were often noticed to stretch beyond the anus, as in Holt's specimen, but this was never the case with fresh or living larvæ derived from the August batch referred to above. Several larvæ measured fresh on the third and fourth days had a length of exactly $5 \mathrm{~mm}$.

Holt remarks upon the delicacy of the larvæ and their susceptibilities to slight injuries, an observation which in the early stages of these experiments I had frequent opportunities of confirming. The water in the jars was at first renewed by siphoning off half the water and pouring slowly from a broad-lipped jug, at first directly and subsequently through a funnel; but the currents produced by the first method, and the impact of the bubbles of air driven down the funnel, were excessive and caused considerable injury. This method was subsequently replaced by allowing the water to enter the jars in a slow stream from a siphon provided with a stopcock. Even the capture of a larva by means of a dipping tube was sufficient to stun and kill it.

If the larvæ are kept in a "plunger-jar," the diameter of the plungerplate in relation to the diameter of the jar is an important item, and any excess which produces eddies of any violence during the movements of the plunger is certain to prove fatal. At first my larvæ were placed in tall bell-shaped hatching jars having a height of 16 inches and an internal diameter of 8 inches. The plunger-plate was circular and had a diameter of $4 \frac{1}{2}$ inches. The plunger made three complete strokes in exactly two minutes, i.e. one plunge, including both down and up stroke, in 40 seconds. The downward stroke was gentle and

\footnotetext{
* Mr. Holt informs me by letter that the total length assigned to the larva in his papers is a mistake due to an error of transcription, and should have been $5.30 \mathrm{~mm}$. After a reexamination of his specimens, however, I find the total length to be the same as in mine, viz. $4.6 \mathrm{~mm}$. (varying between $4 \cdot 55$ and $4 \cdot 65$ ). I have verified the accuracy of my micrometer, so that no difference between our larvæ need be assumed.
} 
occupied 15 or 16 seconds, followed by a pause of 5 seconds, but the upward stroke was smarter and lasted only 8 seconds. The apparatus was then quiescent for about 12 seconds before the next stroke began. The eddies in the water caused by the rapid movements of the plunger were so extensive that the larvæ were frequently caught in the streams and whirled around, and, although these involuntary gyrations did not appear at the time to have any greater effect than to temporarily arrest the activity of the larvæ, I was soon convinced that the mortality which the larvæ exhibited in these first experiments was largely attributable to the incessant harrying to which the movements of the plunger subjected them. When the original plunger-plate was replaced by a much smaller one of $2 \frac{1}{2}$ inches diameter, not only were the water-movements greatly moderated, but the condition of the larvæ generally improved.

The powers of the larvæ in stemming a constant current, however, were considerable. When the water in a jar was being changed, the waste water was at first siphoned off through a glass tube provided with a thistle-funnel (covered with fine gauze) at one end and a stopcock at the other. It was remarkable to notice the success with which both Copepods and young Blenny larvæ could for some time compete with the current setting through the funnel, even when the tap was fully open. As soon as they felt themselves within the influence of the current they would give vigorous darts in the opposite direction, the fishes generally escaping, the Copepods often. But the weaker larvæ which did not dart away smartly enough were drawn up against the gauze. The weakest would remain there, scarcely offering resistance; but the majority, as soon as they touched the tight gauze surface, would give a most powerful leap, and dart clear away from funnel and current alike into relatively still water. Many showed no serious objection to the current itself, and allowed themselves to be drifted up against the gauze; but the moment they felt this obstacle they leaped away as just described. The Copepods, as a rule, were unable to jerk themselves beyond the influence of the current except momentarily, and thus maintained a prolonged contest in the form of incessant darts or leaps from the neighbourhood of the sieve, to be repeated as fast as the current beat them back upon it.

\section{Experiments A, B, AND C.}

The experiments which I made last year fall into four groups (see table p. 76). The first set (A, B, and C) was designed to test the effect of confining the young larvæ in jars of water fitted with Browne's stirring* apparatus known as the "plunger." Three jars of the same size and shape were employed, and were fitted with plungers of equal

* See Journ. M. B. A., v., 1898, p. 176. 
size worked from the same motor. All the jars were filled with water from the offing beyond the Breakwater, but in one (A) the water had been standing in the Laboratory for some weeks and had previously contained Echinoderm larvæ, while in the other two the water was fresh from the sea. One of the latter jars (C) was immersed in a tank of circulating water downstairs in order to maintain a fairly constant temperature; the other (B), together with the jar of stale water, was placed in front of a window facing west, and was fully exposed to the changes of temperature in the air of the building. The same number of larvæ (twenty-five) was placed in each two-gallon jar (August 4th). The larvæ in the stale water were all dead or moribund in three days. Half of the larvæ in each of the remaining jars had died within a week, and all were dead on the tenth day, except one which survived until the fourteenth. The rapid mortality in experiment A was obviously attributable to some impurity in the stale water; that in $\mathrm{B}$ and $\mathrm{C}$ was traceable partly to the excessive movements of the plunger, as described above, partly to insufficient food in the first week, and partly to the over-accumulation of dead plankton in the limited quantity of water.

Table showing, for each experiment, the initial number of larvo, and the number surviving on every fourth day.

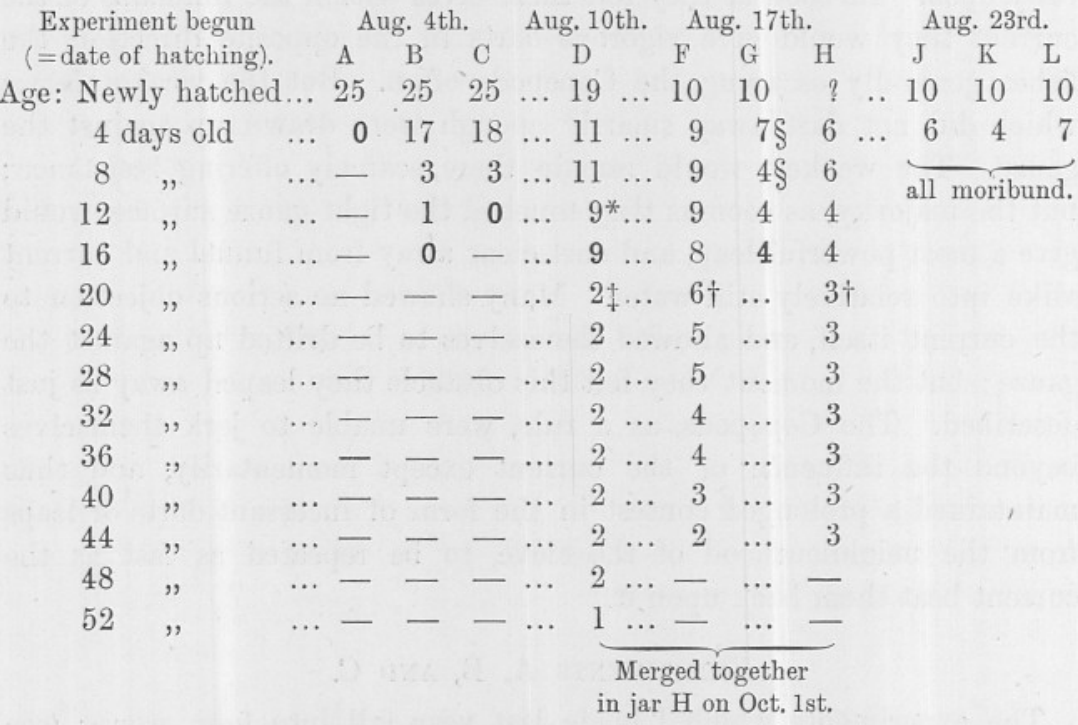

- Deaths caused by the water becoming impure and turbid.

† Deaths caused by mechanical accidents.

‡ Deaths caused chiefly by transference of larvæ to a tank of circulating water in which, by an accident, they were exposed to the attacks of rapacious Copepods.

$\S$ Deaths probably caused by mechanical accidents due to a defect in the jar subsequently discovered (August 26th), and rectified same day. 
These factors so completely dominated the conditions of the experiments that no conclusions could be drawn from the slight differences between the jars at constant and variable temperature, although the heat at the time was so great and the fluctuations in the temperature of the exposed jars were so considerable that further experiments were all carried on in immersed vessels.

The water in the three jars was left unchanged for the first three days of the experiments, but half of the water in each jar was changed daily after this date. To avoid any ill effects from subjecting the larvæ to rapid changes of temperature, the new supplies of "outside water" in these and all other experiments were always raised to the same temperature as the water in the jars before being added. The temperature of the water in these and the remaining experiments described below was daily observed and recorded at about the same hour in the forenoon, 10 to 11.30 a.m., and oftener in certain experiments.

The food supplied was always plankton, which was obtained with fine silk nets beyond the Breakwater as a rule. But no food was given in $\mathrm{A}, \mathrm{B}$, and $\mathrm{C}$ until the fifth day of the experiments, when the larvæ were already four days old. This was a radical error. The larvæ must, to some extent, have been starved, since on this day I found from an examination of the corpses that the yolk had already been absorbed in some, and on the following day was entirely absorbed in eight out of the ten corpses examined. After this date plankton was added daily, and in the remaining experiments was provided from the beginning of each experiment.

The size of the plungers was reduced on the seventh day in B, and on the eighth day in $\mathrm{C}$.

Faeces and plankton débris were removed by a dipping tube at first, and subsequently by a siphon. This was an essential item in each day's operations. If neglected, the larvæ at once began to suffer.

\section{EXPERIMENT D.}

A second experiment (D) was begun a week after the preceding (August 10th), in order to subject a slightly smaller initial number of larvæ (nineteen) to similar conditions, modified, however, by the adoption of a smaller plunger from the second day of the experiment, and by closer attention from the beginning of the experiment to the feeding of the larvæ, and the cleansing and change of the water in the jar. These modifications resulted in a marked reduction of the mortality, especially after the third day, and in a healthier appearance of the larvæ. More than one-third of the larvæ died in the first three days, leaving eleven alive and active on the fourth day of the experiment. These numbers remained unchanged until the eighth day, when one or 
two larvæ were observed to be somewhat feeble, in consequence of the turbidity of the water, and on the ninth day only nine larvæ survived. These, however, after careful cleansing of the jar, were all flourishing. They were growing in bulk, and displayed the greatest activity in their search for food. Their numbers remained unchanged for another week, at the end of which time (the sixteenth day) it was clear that the conditions of the experiment were perfectly suitable for their development, so long as the water could be kept clean and abundance of food could be provided. During the course of the experiment, from onehalf to two-thirds of the water had been changed every day, and fresh plankton added daily with rare exceptions. But irregularities in the quantity and condition of the available plankton were unavoidable, causing occasionally a slight deficiency in the amount provided, and at other times an over-accumulation of dead Copepods, etc., in the jar, and consequent soiling of the water. The larvæ at this time had grown considerably, being about $7.5 \mathrm{~mm}$. in length, and nearly $2.0 \mathrm{~mm}$. in maximum depth, as taken through the hinder part of the eye. The larval fin membrane was still continuous, but the notochord was turned up posteriorly, the tail fin properly formed, the hypural plates and caudal fin-rays established, the fin-rays in the dorsal and ventral fins in process of formation, and the rudiments of the pelvic fins present. There was thus no doubt that the larvæ were growing and developing properly, and were already undergoing the critical stages of their metamorphosis.

On the other hand, the increasing difficulty of keeping their jar clean in consequence of the large amount of food they required, and the death of a larva on the seventeenth day, induced me to remove some of the larvæ from this jar, and see the effect of placing them in a circulation of the ordinary tank water, which would at any rate solve the difficulty of keeping the water clean.

Three of the larvæ were therefore transferred on the eighteenth day to a portable slate tank, with a glass front, holding four gallons of water, and placed in the main laboratory on the south side of the central tanks. The bottom was covered with gravel, and a circulation was set up with every precaution to avoid loss or injury of the larvæ from the current established. On the following day all three were alive and active, whereas another death had occurred in the original plunger-jar. The four survivors were thereupon cautiously' transferred to the portable tank, and a liberal supply of fine plankton was provided. Late in the afternoon only three or four out of the seven were swimming about, the others being on the gravel at the bottom. They appeared to be incommoded by the brighter light of their new situation, so a sheet of green glass was placed in front of the tank. No obvious 
effect on the fishes was noticeable, but the tank was appreciably darkened. Next day five of the larvæ had completely disappeared, and no trace of their remains could be discovered in the gravel or elsewhere. The circulation was all right, and escape by the siphon overflow (a broad funnel imbedded deeply in the gravel) was quite impossible. On further examination it became practically certain that the larvæ had been devoured by Harpacticid Copepods (almost exclusively Idya furcata) which had entered their tank through the siphon from the supply tank above. These Copepods were present in the fishes' tank in myriads-on the slate sides, on the glass, in the gravel, and freely swimming; and I subsequently found, from an examination of the supply tanks, that they abounded in many of these tanks, especially on the glass fronts, from which, in this case, they had clearly been drawn through the siphon supplying the portable tank. The siphon had inadvertently been displaced, so that its mouth rested against the glass front of the supply tank.

The rapacity of these Copepods was easily tested upon dead or moribund larvæ derived from other experiments. The Idya appears to fix itself to its prey by the second antennæ in front, and the second maxillipeds behind. The mandibles, or neighbouring appendages (the precise organs were not determined), then make a rapid series of bites from before backwards, accompanied by an incessant scratching movement carried on by the setæ of the mouth parts. The fin membrane of a larva was quickly gnawed away in semicircular patches, like the holes on the edge of a leaf by caterpillars. To test the rate of dismemberment, three entire corpses of Blenny larvæ were placed at 4 p.m. in a small dish containing sixty-eight Copepods, all of which, as determined after the experiment, were Idya furcata. Next morning the corpses had entirely disappeared except a fragment of one larva, and the faintest possible traces on the sites of the other two.

In order to see whether the Copepods would also attack living prey, I placed four healthy young Gobius minutus, each about one inch long, in the tank. On examining one, which was near the glass front, some time afterwards with a lens, I could see two of the Copepods on the base of the tail fin, busily engaged eating the fin membrane. The Goby appeared to feel no serious discomfort from their proceedings, though it occasionally made restless movements as though slightly irritated. Its movements, which were repeated three or four times while I watched, did not dislodge the Copepods. Next morning one of the Gobies was dead, and had been browsed upon by one at least of its companions, as well as by the Copepods. Its death, however, seemed attributable to the latter.

On the other hand, the Copepods appeared to prefer dead to living 
prey. A moribund Blenny larva was placed in a watch-glass of seawater with a number of the Copepods, and kept under observation under the microscope for twenty minutes. The larva was still capable of spasmodic darts. The Copepods occasionally settled on the larva, but usually left it at once, even when the latter made no signs of objection to their presence. If they remained, and began to feed, the larva would shake them off by wriggling away, though sometimes with difficulty if the Copepod was tenacious. Twelve Copepods visited the larva during the time. Of these, seven left at once, three very soon, and two after being shaken off by the larva. At the end of twenty minutes the moribund larva was removed, and a corpse offered to the same Copepods. In the same time nine Copepods visited the corpse: Of these only three left at once, while the other six remained to feed, some for five minutes, but the majority for the remainder of the experiment. The moribund larva was now weaker; the heart was beating, but the respiratory movements had ceased. It could no longer shake off the Copepods, and these remained to feed precisely as on the corpse.

The above experiments indicate that these carnivorous Copepods, especially Idya furcata, prefer dead prey, but do not hesitate to attack living fishes or larvæ on occasions. Although even Blenny larvæ could probably free themselves of these pests under ordinary circumstances, the extraordinary accumulation of the Copepods in my rearing tank appears to have subjected the larvæ to such incessant attacks from them that they were unable to cope with them, and finally gave way, especially as the second lot of larvæ appears to have been rendered temporarily torpid from the beginning by the change from the plungerjar to the tank-a condition which would reduce their ability to drive off the pests.

I made one further experiment which may provide a useful means of preventing the accumulation of these Copepods in aquaria. A small Wrasse (Ctenolabrus rupestris), 2 inches long, was introduced into the tank when the Copepods were literally teeming within it. Next morning the Wrasse was very lively, and the Copepods were exceedingly scarce. On watching further, I saw the Wrasse busily engaged picking them off the slate walls one by one with unvarying exactitude. Its stomach on dissection was found to be filled with the Copepods.

The result of this instructive accident in my second rearing experiment was that the two larvæ which still survived in the slate tank were again transferred to a plunger-jar as before; and in this they continued to thrive for another month without further incidents calling for notice. They completed their metamorphosis, and one survived to become a sturdy little fish an inch in length, with the entire organisation and habits of the adult, even to the extent of making a house for itself out 
of a small Trochus shell. It was preserved with the survivors from other experiments in the second week of November, at an age of three months (thirteen weeks). Its companion had died a month earlier (October 1st) of a complaint which frequently recurred among the larger fry, and which at this time I did not properly understand. As will be described below, I eventually satisfied myself that this ailment (the principal symptoms of which were a kind of flatulence and an inability to remain below the surface of the water) was a result of the excessive feeding in which the fry frequently indulged after the daily supply of plankton.

\section{Experiments F, G, and $\mathrm{H}$.}

These experiments were begun with a new batch of larvæ a week later than the preceding experiment (August 17th) with the object of determining whether the initial death-rate in the earlier experiments might not be prevented by placing a still smaller number of larvæ in the rearing jars-a plan which would render the larvæ less liable to suffer from the occasional impurity caused by an excess of dead plankton in the limited quantity of water, which could not conveniently be changed more than once a day as a rule. All these experiments, it should be remembered, were begun in the height of a hot summer (August, 1899) when the temperature of the aquarium water stood constantly in the forenoon at about $19^{\circ} .0$ C. (=more than $65^{\circ}$ Fahr.), and varied only between $18^{\circ} \cdot 8$ and $19^{\circ} \cdot 2$ at that time on different days.

Two jars ( $\mathrm{F}$ and $\mathrm{G}$ ) were at first taken, of the same kind as before, and were immersed side by side, under precisely similar conditions, in the same tank of water. The same plunger-plates (diameter $2 \frac{1}{2}$ inches) were also employed, and were worked by the same motor and therefore at the same rate. The only difference between the two experiments that was intentionally introduced was in the character of the water supplied, as I was anxious to compare the mortality of the larvæ when kept in offshore and harbour water respectively. One jar, therefore (F), was kept constantly supplied with inshore water pumped up from immediately below the Laboratory. It was taken from one of the large Laboratory settling reservoirs before being circulated through the aquaria, and was therefore pure unused harbour water. The other jar (G) was supplied with offshore water brought in carboys rom beyond the Breakwater as before. The remaining conditions of the experiment would have been practically identical had it not been for a defect in the latter jar, which was not discovered until nine days after the experiment commenced. The rearing jars are each perforated at the apex for the insertion of a supply pipe (for hatching purposes), but for my purposes these holes were closed by the insertion of corks, 
the inner surfaces of which were covered with a layer of hard paraffin wax to prevent the entrance of impurities from the corks in the inverted position in which they were employed. On the fourth day of the experiment (August 20th) three larvæ in G had completely disappeared, and one had again disappeared three days later (August 23rd) without leaving any trace-a most unusual occurrence. On the 26th, when siphoning off the sediment from the bottom of this jar, I saw a larva sucked into a gap beneath the layer of paraffin covering the cork at the bottom, and was only able to release it with difficulty. The cork had clearly not been driven in quite flush with the outer neck of the jar before the experiment, and had thus been forced inwards to a slight extent after being placed upright in the inverted position, thus detaching the paraffin layer from the inner face of the glass. The crevice so formed was just large enough to allow a larva to enter. This jar was the only one in which such a detachment of the paraffin had taken place, and the defect accounts in all probability for the frequent deaths in $\mathrm{G}$ as compared with $\mathrm{F}$ in the early stages, the larvæ having got in, and either injured themselves or failed to emerge. After the defect was remedied no further deaths occurred in the jar except one on the following day, which probably resulted from the accident which I had observed.

Thus exact comparison between the two experiments is scarcely possible, though the healthy development of the larvæ in $\mathrm{F}$ fortunately renders such comparison unnecessary.

Ten newly hatched larvæ from the same batch of eggs were placed in each of the two jars. They were fed with plankton from the beginning, and half of the water, or even more, according to circumstances, was changed daily in each jar. A summary of the results is shown in the table (p. 76).

The advantage of giving the larvæ a more plentiful supply of water and food from the beginning was clearly shown by the trifling deathrate at the beginning of the experiment, and by the healthy and vigorous condition of the larvæ. In $\mathrm{F}$ one corpse was removed on the second day of the experiment, a death which was almost certainly of an accidental character, but from this day no deaths occurred until the end of a fortnight. The larvæ were active and healthy during the whole of this period until the last few days, when two, which were not growing so rapidly as the others, showed signs of inactivity and died during the following week. Another was lost on the seventeenth day (September 3rd) by being drawn up the siphon during the cleaning of the jar. From this date I was unable to watch the experiments from day to day, owing to absences caused by work at sea and my attendance at the Dover meeting of the British Association. As far as possible, however, 
the same routine was continued in the treatment of the fry in my absence, and two survived the forty-fourth day (September 30th) when they, with the survivors from $\mathrm{D}$ and $\mathrm{H}$, were merged together into the jar devoted to this last-mentioned experiment, the conditions of which appeared to be more suitable than plunger-jars for the later stages of development.

During the course of this experiment the larvæ throve splendidly during the first few weeks, up to a length of about $10 \mathrm{~mm}$., and completed all the essential structural changes in their metamorphosis, the permanent fins having been formed and the skeleton established. They were always very lively, and darted about after Copepods with great agility, displaying much pertinacity and considerable acrobatic powers in their efforts to secure their prey.

Their methods of hunting were always alike, and were so eminently characteristic as to merit a brief description. Upon noticing some fancied morsel, the larva would immediately become transformed with excitement, and, keeping its face constantly towards the object, would commence a series of evolutions, the first purpose of which was to investigate the nature of the prey, and the second to circumvent the latter's escape. Wheeling round through the quadrant of a circle by a series of strokes of the tail, aided by synchronous movements of the pectoral fins, the larva, if satisfied with the result of this preliminary survey, would leap smartly round from side to side of the chosen morsel until by a well-directed forward dart the quarry was seized or frightened away. If the attack were successful, the larva would swim quietly about again; but if unsuccessful, it would swiftly pursue and repeat the same process until success rewarded its efforts or the Copepod finally escaped. The pectoral fins were ceaselessly employed in these movements, whether from side to side, up and down, or even backwards. Under these circumstances Mr. Holt's suggestion* that the large size of the pectorals in these larvæ may be of merely ancestral significance appears unnecessary. It is true, as my colleague remarks, that these fins are not very effective organs of locomotion, so far as pace alone is concerned; but it is impossible to spend any time in watching these larvæ hunting for food without forming the conviction that the fins are particularly adapted to enable their possessors to cope with the peculiar dodging movements of the Copepods they pursue, which resemble to some extent the well-known tricks of the so-called hovering flies of our gardens and hedge-rows (fam. Syrphida).

Resuming my narrative, however, the fry, in later stages, after the third week, did not as a rule appear to do so well in this jar as those in jar $\mathrm{H}$, to be described below. They continued to grow rapidly, but

* Journ. M. B. A., v., 1898, p. 123. 
individuals from time to time had strange fits of torpidity, and at a stage when the larvæ in $\mathrm{H}$ were already settling on the bottom, those in $\mathrm{F}$ showed a marked preference for the surface, which they refused to leave. They were obviously not quite healthy; and, although I adopted a different interpretation later on (see p. 86) in connection with similar phenomena in jar H, I attributed the unhealthiness of the larvæ at the time to the unsuitability of the conditions in the plunger-jar, since after the larvæ were transferred to the stagnant water in $\mathrm{H}$ they assumed habits similar to those of their companions almost immediately (next day).

It is possible, though unlikely, that the ill health of the later larvæ in $\mathrm{F}$ was due to a deterioration in the reservoir water, which was changed a few weeks after the commencement of the experiment. In August the harbour water was doubtless of an exceptionally pure character, in consequence of the long dry summer, but the rains of September must have subsequently affected its salinity and quality in the neighbourhood of the Laboratory, as they undoubtedly drove away the Red Mullet which had previously been lurking about the mouth of the Cattewater in exceptional abundance.

Thus in spite of the low mortality in this experiment during the first few weeks, which points to the suitability of the harbour water at that time, I should hesitate to conclude that the harbour water would be usually suitable for the development of this fish in other years or at other seasons of the year, when the salinity is lowered by the greater quantity of fresh water coming down the Tamar, Tavy, and Plym.

Experiment $\mathrm{G}$ requires little to be said of it in consequence of the initial defects in the jar already alluded to. On the nineteenth day (September 4th), prior to my Channel cruise, I preserved the four survivors in this experiment in order to have some material for studying the anatomical details of the progress made in development. The larvæ varied in length at this stage between $6.8 \mathrm{~mm}$. and $8.0 \mathrm{~mm}$. The maximum depth through the hinder part of the eye was $2.0 \mathrm{~mm}$. in the largest specimen. The notochord was turned up posteriorly in the largest, but scarcely bent at all in the smaller specimens. Two hypural bony plates were developed in the largest, but were quite insignificant in the smallest larva. Delicate caudal fin-rays in fan-like tufts were conspicuous in all, and formed a protruding ventral lobe to the fin in the smaller specimens.

A noteworthy, though not conspicuous feature of the larva up to this stage, and even for another week beyond it, is the permanently gaping mouth. The larvæ do not close their jaws until they are a full month old, when the teeth begin to appear.

Experiment. H was started on August 22nd, in order to see the effect 
of transferring larvæ four or five days old from a plunger-jar to a jar of stagnant water, devoid of a plunger, and aërated by means of green algæ exposed to direct sunlight immediately in front of a south window. The jar was broader than the rearing jars, and of different shape, having a flat bottom and cylindrical sides, and terminating above in a shoulder and a neck about 3 inches in diameter. It contained about 3 gallons when full, but was not filled during the first few weeks beyond about two-thirds or three-quarters of its total height. It was immersed to a little below the same height in a tank of circulating water in the full blaze of the midday and afternoon sun. The current in the outer tank was not strong enough to keep the temperature in the jar constant, but served to moderate it. The following series of temperatures give an idea of the range of temperature to which the larvæ were exposed:-

\begin{tabular}{|c|c|c|c|c|c|c|c|}
\hline \multirow{2}{*}{\multicolumn{2}{|c|}{ Temp. of water in tank }} & Aug. & 25. & Aug. 26 . & Aug. 27 . & Sep. 2. & Sep. 7. \\
\hline & & $\begin{array}{c}10 \text { a.m. } \\
19^{\circ} \cdot 9\end{array}$ & $\begin{array}{l}4 \text { p.m. } \\
21^{\circ} \cdot 0\end{array}$ & $\begin{array}{l}3 \text { p.m. } \\
21^{\circ} \cdot 6\end{array}$ & $\begin{array}{l}\text { Noon. } \\
19^{\circ} \cdot 7\end{array}$ & $\begin{array}{l}2 \text { p.m. } \\
18^{\circ} \cdot 7\end{array}$ & $\begin{array}{l}\text { ? hour. } \\
19^{\circ} \cdot 2\end{array}$ \\
\hline " & , jar (top). & $20^{\circ} \cdot 3$ & $23^{\circ} \cdot 0$ & $24^{\circ} \cdot 1$ & $19^{\circ} \cdot 8$ & $19^{\circ} \cdot 2$ & $20^{\circ} \cdot 0$ \\
\hline , & ", (bottom) & $19^{\circ} \cdot 8$ & $21^{\circ} \cdot 3$ & $21^{\circ} \cdot 6$ & $19^{\circ} \cdot 7$ & $18^{\circ} \cdot 8$ & $19^{\circ} \cdot 2$ \\
\hline
\end{tabular}

As shown by the figures, the uppermost layer of water in the jar was generally warmer than the rest during the daytime, since the outer jacket of circulating water was not high enough to surround it; and the amount of the excess depended on the sunshine, amounting to $2 \frac{1}{2}^{\circ}$ C. on hot afternoons (e.g. August 26th) or of a mere fraction of a degree on cloudy days (August 27th, September 2nd). The bottom temperature amounted to $22^{\circ} \cdot 0$ at 4 p.m. on August $23 \mathrm{rd}$, but rarely exceeded $21^{\circ} \cdot 0$ after the first few days.

A small tuft of Ectocarpus was placed at the bottom of the jar under a small glass funnel as a means of aërating and purifying the water. During sunshine the small bubbles of oxygen emitted by the plant escaped into the surrounding water in a continuous stream through the narrow aperture of the funnel; and in a very short time the bottom and sides of the jar became covered with a perfect jungle of the same alga from the fixation and development of the spores liberated by the original tuft, which, with the funnel, was then removed.

Into this jar, on August 22nd, were placed six larvæ derived from the same batch of eggs as those in experiments $F$ and $G$, but they were already from four to five days old at the time of their introduction. Previous to this they had been kept in a plunger-jar (E) under the same external conditions as F and G. They had not, however, received much attention. The six larvæ were the survivors of ten or eleven which had been isolated on the 18th (from twelve to twenty-four hours after hatching), and had received no change of water and only one 
supply of plankton in the interval. The feebler larvæ may therefore be supposed to have been already weeded out.

In the new jar $(\mathrm{H})$ the larvæ were subjected to the same attention as those in $\mathrm{F}$ and $\mathrm{G}$; that is, the water was partially changed every day, a daily supply of plankton was provided, and débris and faeces were removed every morning by means of a siphon.

Although no deaths occurred during the first four days, the larvæ did not thrive so well at the beginning as in the plunger-jars. Several of them from the beginning showed signs of torpidity and lay about on the bottom in a listless condition, possibly in consequence of the greater heat to which they were subjected, possibly also from the lack of motion in the water. Two deaths soon resulted. The remainder, however, became increasingly active, and two in particular began to grow at an unusually rapid rate, soon outstripping their companions. The improvement coincided with a cessation of the excessive heat towards the end of August. On the 30th of August they were all lively, and one was particularly large, being to all appearances as far advanced as the two survivors in D at the same date, although a full week younger. The tail fin was formed, as well as the early skeleton. My diary for the 30th states: "All these larvæ are very healthy and are incessantly swimming. They seem to be in no need of a plunger at this stage." Except the two cases recorded above, no deaths whatever occurred in this jar up to the end of October, when the larvæ were seventy-four days old. The reduction in the number between the sixteenth and twentieth days shown in the table ( $p$ 76) was caused by one being accidentally lost during the changing of the water on September 5th. Occasionally one or other of the largest fry exhibited temporary fits of ill health. The fish would lie at the top of the water, immediately beneath the surface film, spasmodically wriggling and often curling up as if in pain. The abdomen in such cases was always distended with food and gas, and the whole body was lighter than the water, so that the fish could not do otherwise than float at the top. I could diagnose the complaint in no other way than as a kind of flatulence or dyspepsia resulting from over-feeding. I fear this explanation may seem to others to savour of anthropomorphism, but I can only point to the fact that before I arrived at this explanation several deaths occurred in jars $\mathrm{D}$ and $\mathrm{F}$ from similar causes, from inability to treat the cases properly, whereas, after I became convinced of it, I repeatedly brought these ailing fishes back to health again by reducing their supplies of food. It should be borne in mind that fish larvæ in the sea are never surrounded by such quantities of food in small compass as these fry confined to the space of a two or three gallon jar in my experiments, especially as no attempt was made to spread the supplies of food over a long portion of 
the day. When the tow-nettings arrived, the bottles were always allowed to stand for a few minutes in a convenient position near the jars, so that the Copepods might concentrate themselves near the source of light. They were then poured directly into the jars, or siphoned in, according to the degree of cheir concentration. Thus the fishes were surrounded by a superabundance of food during a portion of the day, and as their instincts were obviously to catch a Copepod whenever the chance presented itself, it is scarcely surprising that they should have occasionally suffered from an excessive diet. For rearing work on a larger scale I therefore believe that one of the many principles that will need attention will be to avoid the possibility of the larvæ enjoying these periodic surfeits by securing a more uniform supply of food for the fry than was attempted in these preliminary experiments.

On October 1st, when the larvæ in $\mathrm{H}$ were forty-five days old, my diary states that the fry were all healthy and that they were already giving up their pelagic habits so as to rest for considerable intervals on the bottom of the jar, from which they would rise, however, from time to time in search of food or from mere love of movement.

On this day, as already related, I transferred the three survivors from experiments $\mathrm{D}$ and $\mathrm{F}$ to the same jar, in which they lived together without loss for another period of five weeks, i.e. to the end of the first week in November, although the smallest was removed on the 1st of this month for preservation and anatomical examination.

It measured $15 \mathrm{~mm}$. in length, and the length of the pectoral fin was $4.9 \mathrm{~mm}$. The dorsal fin possessed twenty-six rays $(12+14)$; the anal, eighteen; and the caudal eighteen rays. The mandible, which protruded in front of the upper jaw, possessed four teeth on each side of a median gap. Teeth were also present in the upper jaw, but were not counted. The supraorbital tentacles were invisible to the naked eye, but could be detected with a lens as a pair of short unpigmented papillæ situated vertically above the most anterior margin of the pupil of the eye. The eyes were set far forward, their anterior margins coinciding with the frontal margin of the head. The pupil alone was blue or black, the iris being golden. The black chromatophores on the head formed a continuous sheet and were not arranged in radii. The colour of the body (both living and preserved in formalin) was dark brown, almost black, over the whole head region (top and sides), over the anterior half of the abdomen, and over the pectoral and pelvic fins. The entire caudal region was colourless and transparent excepting a single line of chromatophores along the base of the anal fin. A line of internal pigment ran along the spinal column as far back as the fifth ray of the posterior dorsal fin.

The other Blennies, five in number, appeared to vary at this time 
from about $16 \mathrm{~mm}$. to $22 \mathrm{~mm}$. in length. The actual dimensions a fortnight later are given below.

Up to this time (the end of October) the fry had been regularly fed with plankton, but at the end of this period the available supplies of large Copepods became much reduced, partly from the impoverishment of the plankton which normally takes place in autumn, and partly from bad weather in November, which interfered with the work of collection. The fry would no longer attack the smaller Copepods (Oithona, Paracalanus, Acartia, etc.), and Calanus was not obtainable. No Crabs, Prawns, or Shrimps could be found in berry, except isolated specimens carrying new-laid eggs, which the fish refused to touch. I therefore tried feeding them with bits of chopped Prawn. They would occasionally seize morsels as they fell through the water, but not after the fragments had settled on the bottom. On the 6th of November one of the largest Blennies died, almost certainly of starvation, owing to the difficulty of providing suitable food. On the 9 th I introduced a number of small Crustacea (Mysidæ, Cumacea, and Amphipods) obtained by working a tow-net immediately above the sandy bottom in Cawsand Bay. A more successful diet was provided on the following day by working a cheese-cloth net over the Zostera bed in the same locality, which brought in a number of small Terebellid and Nereid worms with a few Crustacea. The results were excellent, for the wriggling movements of the worms after they were thrown into the jar at once attracted the attention of the fishes, which snapped them up with avidity. The Nereids appeared to prick the fishes and to be relatively unpalatable, but the Terebellids were eaten with great satisfaction. The largest of the surviving Blennies, which had been ailing during the past week, and had refused all food, now began to recover, and shared the new food with the others. I saw it capture quite a large Amphipod, which, after a little difficulty, it succeeded in swallowing. Only one further incident demands notice. On the 8 th of November, having observed that for several days past a piece of Ulva frequently had one of the fishes underneath it, I introduced a number of small empty Gastropod shells, chiefly Trochus, into the jar. One of the little Blennies at once tucked himself inside one, resting on his pelvic fins, with his head outwards near the orifice, in all respects like the adult fish. A little later there were two fish inhabiting shells. The adoption of this habit at so early a period was not only a sign that the fry had completely departed from the pelagic habits of the larval stages, but is interesting from a general point of view. It shows that the conchicolous habit of the adult fish is not a mere nesting device for the protection of the eggs, but is adopted at probably all stages of growth for concealment and protection. 
The object of the experiments being now achieved, I decided to preserve the little fishes at this stage (three months old) in order to have material for a detailed account of their development.

The young fishes, even in the preserved condition, are attractive little objects. Compared with young salmon or trout fry of the same length, they are seen to be much more robust, partly owing to the shortness and distension of the abdominal region. In the young trout the ventral surface of the body from mouth to tail forms a practically straight line, while the dorsal surface is evenly arched; in the young Blenny the dorsal surface is straight, and the ventral is arched. The greatest depth of the body in the young trout lies nearly midway between the mouth and the base of the tail; in the Blenny it occurs immediately behind the head.

The skin is darkly pigmented with black chromatophores over the front half of the body, but is still colourless and transparent in the posterior part of the caudal postanal region. Behind the head the dark brown pigment is distinctly arranged in a series of vertical bars. A broad bar covers the front half of the abdominal region, and extends over the anterior part of the first dorsal fin. After a narrow interval, a narrower and more clearly defined bar extends across the hindmost region of the abdomen at the boundary between it and the caudal region. Corresponding with this bar, though slightly anterior to it, is the black ocellus of the first dorsal fin, which extends between the sixth and eighth fin-rays, and is well defined in the larger specimens, though still undeveloped in the two smallest. From the ocellus to the ventral margin of the body the bar follows a backwardly directed curve, which becomes almost vertical below the region of the lateral line. The alternating pigmented and unpigmented stripes are of about equal width, equivalent to about the width of two adjacent interspaces between the dorsal fin-rays. In the caudal (postanal) region, only one of these bars is completely formed, but an additional one is distinctly indicated in the largest specimens. The brown pigmentation of the trunk thus extends backwards as growth proceeds, not as a continuous sheet, but in the form of vertical stripes.

Yellow and red chromatophores are also present, but are not easily located.

The pupil of the eye is black, without any suggestion of blue. The iris has a golden basis, obscured to a large extent by black chromatophores.

The pectoral and pelvic fins are covered with black chromatophores. An interesting series of changes in the colour of the pectoral fins took place during growth. In the newly hatched larva these organs were black, as figured by Holt; but about a week or ten days afterwards, if 
development had proceeded normally (as in my experiments D, F, G, and $\mathrm{H}$ ), the black chromatophores were kept constantly contracted, the resulting colour being a bright greenish yellow. This condition was retained until the end of the third week, when the black chromatophores began to be partially relaxed, producing a distinct green-finned stage, which gradually passed into the ultimate dark-finned condition, the change being more or less synchronous with the abandonment of pelagic habits.

The supraorbital tentacles are larger than in the specimen $15 \mathrm{~mm}$. long described above, and are pigmented. They can be seen in the larger specimens without the aid of a lens.

The lower jaw does not protrude beyond the upper in any of these specimens. In other structural details the fry do not materially differ from the smaller specimen already described. The eyes in all specimens are set equally far forward.

The dimensions of the body and number of fin-rays in all five fishes are given in the subjoined table. To complete the series I have added the figures already given for the specimen killed on November 1st:-

\begin{tabular}{|c|c|c|c|c|c|c|c|}
\hline \multirow{4}{*}{ Age. } & \multicolumn{3}{|c|}{ Maximum } & • & \multicolumn{3}{|c|}{ Number of Fin-rays. } \\
\hline & Lengt & & Depth. & & Dorsal. & Anal. & Caudal. \\
\hline & $25.5 \mathrm{r}$ & $\mathrm{nm}$. & $6.6 \mathrm{~mm}$. & $\ldots$ & $11+14$ & 17 & 20 \\
\hline & $24 \cdot 5$ & $\eta$ & $6 \cdot 6$, & $\ldots$ & $11+14$ & 17 & 20 \\
\hline \multirow[t]{3}{*}{13 to 14 weeks } & $24 \cdot 5$ & $"$ & $6 \cdot 4$, & $\ldots$ & $11+14$ & 17 & 19 \\
\hline & 21.5 & , & $6 \cdot 3 \%$ & ... & $11+14$ & 17 & 17 \\
\hline & 19 & $"$ & $5.0 "$ & $\ldots$ & $11+14$ & 17 & 20 \\
\hline 11 weeks & 15 & , & 4.0, & $\ldots$ & $12+14$ & 18 & 18 \\
\hline
\end{tabular}

In explanation of the figures I should add that the length of body includes the caudal fin; but the depth has been determined from the base of the dorsal fin to the ventral surface, the exact line being drawn across the base of the pectoral fins. The number of fin-rays was in each case determined with the microscope.

It will be noticed that the number of dorsal and anal fin-rays is remarkably constant, since it is identical in five out of six specimens. The abnormality which occurs in the smallest fish is apparently not a variation due to difference of size, but a true individual variation affecting the upper and lower fin alike. The caudal fin is subject to greater variation, partly due to growth.

On comparing these numbers with those assigned by Holt to the later larva figured in his paper, * a considerable difference is noticeable, since Holt's larva, having a body length of $18 \mathrm{~mm}$., possessed twenty-seven dorsal $(12+15)$ and nineteen anal rays, thus exceeding by one dorsal and one anal ray the numbers exhibited by the abnormal specimen in

\footnotetext{
* Ann. Mus. Hist. Nat. Marseille, 1899, p. 46, pl. 6, fig 64.
} 
my series. The identification of Holt's larva* with Blennius ocellaris was admittedly tentative; but in view of the data now available, I am inclined to think that this identification should be abandoned, and that the larva should be provisionally referred to $B$. trigloüdes.

In support of this suggestion I would point principally to the difference between my specimens and Holt's description and figure in regard to the position and colouration of the eye, the pigmentation of the head, and the possession of preorbital and supraorbital tentacles.

The eye in Holt's figure is set much further back than in any of my larvæ; there is no trace in the latter of the radial arrangement of facial pigment which is so prominent a feature in my colleague's specimen; and the preorbital tentacle figured by Holt has no counterpart in my larvæ. This tentacle is not referred to in the text of Holt's description, but can only represent the tentacle which in several species of Blenny is situated at the anterior orifice of the nares. According to Moreau the nasal tentacle is found both in $B$. incequalis and $B$. trigloüdes, but is sometimes wanting in $B$. ocellaris. On the other hand, a supraorbital tentacle is found in $B$. incequalis and $B$. ocellaris, but not in B.trigloïdes. In Holt's larva the supraorbital tentacle appears to have been wanting, but is distinctly developed in my larvæ, even at a smaller size. Consequently it is probable that Holt's larva should be referred to B. trigloïdes.

In general features, however, Holt's figure gives a fairly good idea of the proportions of the body in larvæ of $B$. ocellaris at the same stage. $\dagger$

\section{Experiments J, K, AND L.}

These experiments were begun with a new batch of larvæ on August 23rd, after I had already gained considerable experience as to their habits, in order to determine whether agitation of the water was necessary or not for their successful development during the period immediately after hatching, care being taken that the water should be thoroughly oxygenated, and that ample supplies of food should be present in the water from the beginning.

Shallow rectangular glass aquaria were chosen for the experiment, since they presented a large surface for aëration of the water. They were immersed in the circulating water of the aquarium tanks, in order to preserve a fairly constant temperature; and were filled with the same water as was proving so successful with experiment F. No plunging apparatus was set up, and no convection currents were possible under the conditions of the experiment, the water being absolutely stagnant. Ten active larvæ hatched the same day were placed in each jar.

* I have since had an opportunity of examining this specimen, which is far more slender and of less robust appearance than my larvæ at the same stage. It should certainly be assigned to a different species.

$+\mathrm{My}$ friend and pupil, Mr. Arthur Darbishire, of Oxford, is kindly preparing some figures illustrating the development of $B$. ocellaris with a view to publication. 
Jar $\mathrm{J}$ was larger than the other two, and measured 18 inches long by 12 inches wide and 6 inches deep. This was immersed side by side with jars $\mathrm{D}$ and $\mathrm{F}$ in one of the table tanks of the aquarium.

Jars $\mathrm{K}$ and $\mathrm{L}$ were identical in shape and size, and measured 12 by 8 by 4 inches. They were immersed in the same tank as jar $H$ in front of a south window.

One-quarter of the water was changed each day and fine plankton was added each morning, as in the early days of experiments $\mathrm{F}$ and $\mathrm{G}$.

The early results of the experiments are shown in the table (p. 76). Two of the losses recorded (one in $J$, and one in L) resulted from accidents in changing the water, but from the second day of the experiment it was obvious that the larvæ were doing badly. A few swam about a little in the early days, more particularly in $\mathrm{J}$, but the vast majority were very listless and inactive, making no efforts to feed, and lying passively on the bottom of the jars or at the very surface of the water immediately below the surface film. Their movements were limited to occasional spasmodic jerks, contrasting markedly not only with the movements of the larvæ in the plunger-jars D, F, and G, at a corresponding stage, but also with their own movements in the plunger-jar in which they were hatched, previously to their transference to the stagnant water. On the fifth day, when they were four days old, their numbers were reduced to six, four, and seven respectively; and all, except one or two in $J$, were exceedingly torpid and several in $\mathrm{L}$ were on the point of death. The experiments were continued a few days longer with no favourable change in the condition of the larvæ and an increasing number of deaths; but, as the results were already conclusive, I soon afterwards abandoned the experiments as not worthy of further attention.

The behaviour of the larvæ was precisely similar to that described with such careful detail by Fabre-Domergue and Biétrix in their admirable experiments upon Cottus and other forms, the principal symptom of which was the progressive anæmia and "etiolation" to which the larvæ in all their experiments fell victims. These naturalists at first* attributed these results to the noxious influence of the water in confinement, the precise nature of which was undetermined; but in a later note $\dagger$ they account for the result as more probably due to the failure to provide the larvæ with the food most suitable to them at the particular stage of growth.

I quite agree with the French naturalists, as well as with Mr. Harald Dannevig (loc. cit.), as to the necessity of supplying the larvæ with suit-

* Ann. Sci. Nat., viii., 1897, pp. 212-17.

+ Role de la Vésicule Vitelline dans la Nutrition larvaire des Poissons marins. Comptes Rendus dés Séances de la Société de Biologie, 30th Avril, 1898. 
able food before the complete absorption of the yolk; but, in view of the precautions taken in my experiments, I can adopt no other explanation of the debility of the larvæ in experiments $\mathrm{J}, \mathrm{K}$, and $\mathrm{L}$ than that it was directly attributable to the absolute stagnancy of the water. Gentle movements of the water appear to be indispensable to the healthy development of fish-larvæ in the earliest stages after hatching; and I believe the physiological explanation of this necessity is to be sought in the stimulus to exercise and movement which the larvæ derive from the play of the currents. I am strengthened in this opinion by the successful results attained by Mr. Harald Dannevig in his experiments on the rearing of plaice larvæ, since he attached considerable importance in his experiments to the movements of the water brought about by convection currents. I am, however, strongly inclined to believe that a far greater percentage of larvæ would have survived in Dannevig's experiments if he had placed a much smaller number of larvæ in the ten-gallon jar he employed, and if he had amplified the currents by some mechanical contrivance in the first week or fortnight of development.

\section{CoNCLUSIONS.}

From the experiments detailed in the preceding pages it appears reasonable to conclude that the conditions which are most important for the healthy development of sea-fish larvæ, and to the survival of a high percentage of fry through the critical stages of the metamorphosis, are the following:-

(1) A liberal supply of pure water;

(2) Mechanical, but moderate, agitation of the water until the larvæ have become thoroughly active and accustomed to catch the food provided them;

(3) Provision of suitable food prior to the absorption of the yolk; and

(4) A fairly constant, but not excessive, supply of food each day, which should be introduced in frequent small doses, rather than in single concentrated supplies.

Reviewing the evidence, I am inclined to think that the water problem can best be solved in large experiments by maintaining a constant slow current through the rearing tanks, with plungers or other stirring apparatus in addition, so long as necessary. The former would tend to keep the water pure, the latter would give the larvæ a healthy start in the important matters of exercise and general activity. The precise method by which the food should be administered would depend largely on the species to be reared, since different larvæ are now known to have well-marked preferences for different articles of food. 